\title{
Profil penderita karsinoma sel ginjal (renal cell carcinoma) di RSUP Prof. Dr. R. D. Kandou Manado periode 2013-2015
}

\author{
${ }^{1}$ Jenny Melisa \\ ${ }^{2}$ Alwin Monoarfa \\ ${ }^{2}$ Fedinand Tjandra
}

\author{
${ }^{1}$ Kandidat Skripsi Fakultas Kedokteran Universitas Sam Ratulangi Manado \\ ${ }^{2}$ Bagian Ilmu Bedah RSUP. Prof. Dr. R. D. Kandou Manado \\ Email: jennymelisaumboh@gmail.com
}

\begin{abstract}
Renal cell carcinoma or Grawitz tumor is a tumor originating from the proximal tubular epithelial and 3\% of malignant tumors in adults. The cause of this disease appeared was not accurately known but this disease can occur all over the world, depend on their ages, sex and race. Smoking and obesity are the most common cause of this tumor. This study was aimed to determine the profile of patients with renal cell carcinoma in the RSUP of Prof. Dr. R. D. Kandou Manado period 2013-2015 based on number of patients, age, sex, location, metastasis, histopathology results, complaints, and treatments. This was a descriptive retrospective study using data of the Medical Record and Department of Pathology of Prof. Dr. R. D. Kandou Hospital Manado. The results showed that the distribution of patients with renal cell carcinoma in 2013 until 2015 was the highest in $2015(62.5 \%)$. Th majority of cases were males (2:1), age group 51-65 yrs (50\%) with back pain (87.5\%). unilateral location of the renal cell carcinoma $(100 \%)$ in right position $(56.25 \%)$, and without metastasis $(62.5 \%)$. Many histopathological results could not be found or missed (56.25\%). Most patients were treated with nephrectomy $(56.25 \%)$.
\end{abstract}

Keywords: renal cell carcinoma, profile, manado

\begin{abstract}
Abstrak: Karsinoma sel ginjal atau tumor Grawitz merupakan tumor yang berasal dari epitel tubulus proksimal dan merupakan 3\% dari tumor ganas pada orang dewasa. Penyebab penyakit ini belum diketahui secara pasti namun dapat terjadi di seluruh dunia dan tergantung pada umur, jenis kelamin, dan ras. Merokok dan obesitas merupakan penyebab terbanyak dari tumor ini. Penelitian ini bertujuan untuk mengetahui profil penderita karsinoma sel ginjal di RSUP Prof. Dr. R. D. Kandou Manado Periode 2013-2015, dan untuk mengetahui gambaran distribusi berdasarkan jumlah penderita, umur, jenis kelamin, letak, metastasis, hasil histopatologi, keluhan dan penanganan. Jenis penelitian ialah deskriptif retrospektif dengan menggunakan data di bagian Rekam Medik dan Patologi Anatomi RSUP Prof. Dr. R. D. Kandou Manado. Hasil penelitian menunjukkan bahwa distribusi penderita karsinoma sel ginjal periode 2013-2015 terbanyak pada tahun 2015 (62,5\%), dan tertinggi pada kelompok umur 51-65 tahun (50\%). Jumlah pasien laki-laki lebih banyak daripada perempuan (2:1). Letak karsinoma sel ginjal terbanyak yaitu unilateral $(100 \%)$ pada posisi dekstra $(56,25 \%)$. Untuk hasil histopatologik, banyak data yang tidak ada atau hilang $(56,25 \%)$. Keluhan tersering pada penyakit ini yaitu nyeri pinggang $(87,5 \%)$. Sebagian besar penderita tidak mengalami metastasis $(62,5 \%)$ dan penanganan terbanyak yang dilakukan ialah nefrektomi $(56,25 \%)$.
\end{abstract}

Kata kunci: karsinoma sel ginjal, profil, manado

Ginjal merupakan sepasang organ yang terletak di belakang rongga peritoneum. Ginjal sangat berperan dalam filtrasi, metabolisme dan ekskresi. Seperti organ tubuh yang lainnya, ginjal juga bisa mengalami karsinoma atau kanker. Kanker ginjal adalah penyebab kematian paling umum ke-16. Tumor ginjal merupakan 
tumor urogenitalia nomor tiga terbanyak setelah tumor prostat dan tumor kandung kemih. Tumor ginjal dapat berasal dari tumor primer di ginjal atau pun merupakan tumor sekunder yang berasal dari metastasis keganasan di tempat lain. ${ }^{1}$

Statistik menunjukkan bahwa insiden kanker ginjal dua kali lebih banyak pada pria dibandingkan wanita dan 59\% kasus kanker ginjal terjadi di negara-negara berkembang, dengan tingkat tertinggi terlihat di Amerika Utara dan Eropa dan terendah terlihat di Asia dan Afrika. ${ }^{2}$

Adenokarsinoma ginjal atau renal cell carcinoma sering disebut juga hipernefroma atau tumor Grawitz. Renal cell carcinoma (RCC) mencakup 2-3\% dari seluruh kasus kanker di seluruh dunia dan keganasan urologi tersering ketiga setelah prostat dan buli. $^{3}$ Karsinoma sel ginjal merupakan 3\% dari seluruh tumor ganas pada orang dewasa yang ditemukan pada umur 40-70 tahun. Kejadian tumor pada kedua sisi (bilateral) hanya terdapat pada 2\% kasus saja. Angka kejadian pada pria lebih banyak daripada wanita dengan perbandingan 2:1. Di seluruh dunia, sekitar 270.000 kasus baru di diagnosis per tahun, dan sekitar 116.000 pasien meninggal per tahun. ${ }^{4}$

Data lain menunjukan bahwa di seluruh dunia terdapat 209.000 kasus baru dan 102.000 meninggal per tahunnya. ${ }^{5}$ Insiden RCC tertinggi terjadi di negaranegara Barat dan terendah di negara Asia dan Afrika. Pada tahun 2015 di Amerika Serikat, sekitar 62.000 telah di diagnosis RCC dan 14.000 telah meninggal karena kasus ini. ${ }^{6}$

Pada tahun 2012, terdapat sekitar 84.400 kasus baru RCC dan ada 34.700 kematian akibat kanker ginjal di Uni Eropa. Di beberapa negara Eropa (Kroasia, Estonia, Yunani, Irlandia, Slovakia), tingkat kematian masih menunjukkan peningkatan. Jumlah penderita RCC di Rumah Sakit Cipto Mangunkusumo (RSCM) pada tahun 1995-2009 sebanyak 99 orang (33\% dari seluruh kasus kanker ginjal). ${ }^{6}$

Diperkirakan $18 \%$ dari pasien dengan
RCC memiliki metastasis pada saat di diagnosis; $61 \%$ pasien dengan RCC memiliki metastasis di satu tempat, dan $39 \%$ memiliki metastasis di beberapa tempat. Metastasis paru merupakan metastasis tersering pada RCC yakni terhitung 45\%. Untuk metastasis tulang terdapat $30 \%$ pada semua pasien dengan RCC. Metastasis kelenjar getah bening merupakan ketiga metastasis RCC, sekitar $22 \%$ kasus sedangkan $20 \%$ pasien dengan RCC menghasilkan metastasis hati. Untuk metastasis kelenjar adrenal dari RCC jarang, hanya sekitar 9\% dan untuk metastasis otak dari kasus RCC hanya $8 \%$. $^{7}$

\section{METODE PENELITIAN}

Jenis penelitian ini ialah deskriptif retrospektif dengan menggunakan data sekunder dari RSUP Prof. Dr. R. D. Kandou Manado dan Bagian Patologi Anatomi periode 2013-2015 dengan pengambilan data pada bulan Oktober 2016 sampai bulan November 2016. Subjek penelitian ialah semua pasien penderita karsinoma sel ginjal yang datang berobat di RSUP Prof. Dr. R. D. Kandou Manado periode 2013-2015

Kriteria inklusi yaitu semua penderita yang didiagosis karsinoma sel ginjal yang dibuktikan dengan pemeriksaan histopatologik dan penderita yang dirawat di RSUP Prof. Dr. R. D. Kandou Manado periode 2013-2015. Data kasus yang diperoleh diolah menggunakan Microsoft Excel dengan analisis distribusi.

\section{HASIL PENELITIAN}

Jumlah penderita karsinoma sel ginjal sebanyak 16 kasus yang didapatkan di bagian Rekam Medik RSUP Prof. Dr. R. D. Kandou Manado periode 2013-2015.

Berdasarkan data angka kejadian karsinoma sel ginjal di RSUP Prof. Dr. R. D. Kandou Manado, ditemukan 2 kasus (12,5\%) pada tahun 2013, 4 kasus $(25 \%)$ pada tahun 2014, dan 10 kasus $(62,5 \%)$ pada tahun 2015 (Tabel 1).

Dari Tabel 2 dapat dilihat bahwa pada kelompok umur 21-35 tahun terdapat 1 kasus (6,25\%), kelompok umur 36-50 
tahun terdapat 6 kasus $(37,5 \%)$, kelompok umur 51-65 tahun terdapat 8 kasus (50\%), dan kelompok umur $>65$ tahun terdapat 1 kasus $(6,25 \%)$.

Tabel 1. Distribusi Penderita Karsinoma Sel Ginjal berdasarkan Tahun

\begin{tabular}{ccc}
\hline \hline Tahun & Frekuensi & $\%$ \\
\hline 2013 & 2 & 12,5 \\
2014 & 4 & 25 \\
2015 & 10 & 62,5 \\
\hline Total & 16 & 100 \\
\hline \hline
\end{tabular}

Tabel 2. Distribusi Penderita Karsinoma Sel Ginjal berdasarkan Umur

\begin{tabular}{ccc}
\hline \hline Umur & Frekuensi & $\%$ \\
\hline $21-35$ & 1 & 6,25 \\
$36-50$ & 6 & 37,5 \\
$51-65$ & 8 & 50 \\
$>65$ & 1 & 6,25 \\
\hline Total & 16 & 100 \\
\hline \hline
\end{tabular}

Dari Tabel 3 dapat dilihat ditribusi penderita karsinoma sel ginjal berdasarkan jenis kelamin. Jenis kelamin laki-laki yang menderita karsinoma sel ginjal adalah sebanyak 11 kasus $(68,75 \%)$ sedangkan perempuan sebanyak 5 kasus $(31,25 \%)$.

Tabel 3. Distribusi Penderita Karsinoma Sel Ginjal berdasarkan Jenis Kelamin

\begin{tabular}{ccc}
\hline \hline Jenis & Jumlah & $\%$ \\
Kelamin & & \\
\hline Laki-laki & 11 & 68,75 \\
Perempuan & 5 & 31,25 \\
\hline Total & 16 & 100 \\
\hline \hline
\end{tabular}

Dari Tabel 4 dan 5 dapat dilihat distribusi karsinoma sel ginjal berdasarkan letak. Dari 16 penderita karsinoma sel ginjal, 16 penderita mengalami karsinoma sel ginjal letak unilateral $(100 \%)$, dimana 7 kasus $(43,75 \%)$ mengalami karsinoma sel ginjal pada posisi sinistra dan 9 kasus $(56,25 \%)$ mengalami karsinoma sel ginjal pada posisi dextra.

Dari Tabel 6 dapat dilihat hasil histopatologi karsinoma sel ginjal. Dari 16 penderita karsinoma sel ginjal, di dapatkan
7 penderita $(43,75 \%)$ dengan hasil clear cell, dan 9 penderita $(56,25)$ dengan hasil tidak diketahui.

Tabel 4. Distribusi Penderita Karsinoma Sel Ginjal berdasarkan Letak (1)

\begin{tabular}{ccc}
\hline \hline Letak & Jumlah & Persen \\
\hline Unilateral & 16 & 100 \\
Bilateral & 0 & 0 \\
\hline Total & 16 & 100 \\
\hline \hline
\end{tabular}

Tabel 5. Distribusi Penderita Karsinoma Sel Ginjal berdasarkan Letak (2)

\begin{tabular}{ccc}
\hline \hline Letak & Jumlah & Persen \\
\hline Dextra & 9 & 56,25 \\
Sinistra & 7 & 43,75 \\
\hline Total & 16 & 100 \\
\hline \hline
\end{tabular}

Tabel 6. Distribusi Penderita Karsinoma Sel Ginjal berdasarkan Hasil Histopatologi

\begin{tabular}{ccc}
\hline \hline $\begin{array}{c}\text { Hasil } \\
\text { Histopatologi }\end{array}$ & Jumlah & $\%$ \\
\hline Clear Cell & 7 & 43,75 \\
Tidak Diketahui & 9 & 56,25 \\
\hline Total & 16 & 100 \\
\hline \hline
\end{tabular}

Dari Tabel 7 dapat dilihat hasil keluhan penderita karsinoma sel ginjal. Dari 16 kasus karsinoma sel ginjal, didapatkan 14 kasus $(87,5 \%)$ mengalami nyeri pinggang dan 2 kasus $(12,5 \%)$ tidak mengalami nyeri pinggang. Dari 16 penderita karsinoma sel ginjal, didapatkan 5 kasus $(31,25 \%)$ didapati adanya massa, dan 11 kasus $(68,75 \%)$ tidak didapatkan adanya massa. Dari 16 kasus karsinoma sel ginjal, didapatkan 2 kasus (12,5\%) mengalami hematuria dan 14 kasus $(87,5 \%)$ tidak mengalami hematuria. Dari 16 kasus karsinoma sel ginjal, didapatkan 2 kasus (12,5\%) mengalami anuria dan 14 kasus $(87,5 \%)$ tidak mengalami hematuria. Dan dari 16 kasus karsinoma sel ginjal, didapatkan 4 kasus (25\%) mengalami keluhan lain (demam, lemah badan, turun berat badan dan nafsu makan menurun) dan 12 kasus (75\%) tidak mengalami keluhan lain 
Tabel 7. Distribusi Penderita Karsinoma Sel Ginjal berdasarkan Keluhan

\begin{tabular}{cc}
\hline \hline Keluhan & Jumlah \\
\hline Nyeri & 14 \\
Massa & 5 \\
Hematuria & 2 \\
Anuria & 2 \\
Lain-lain & 4 \\
\hline \hline
\end{tabular}

Dari Tabel 8 dapat dapat dilihat hasil metastasis penderita kasinoma sel ginjal. dari 16 kasus, 4 penderita (25\%) mengalami metastasis ke paru-paru, 2 penderita $(12,5 \%)$ mengalami metastasis ke hepar, dan 10 penderita $(62,5 \%)$ tidak mengalami metastasis.

Tabel 8. Distribusi Penderita Karsinoma Sel Ginjal berdasarkan Metastasis

\begin{tabular}{ccc}
\hline \hline Metastasis & Jumlah & $\%$ \\
\hline Paru-paru & 4 & 25 \\
Hepar & 2 & 12,5 \\
Tidak ada & 10 & 62,5 \\
Metastasis & & \\
\hline Total & 16 & 100 \\
\hline \hline
\end{tabular}

Dari Tabel 9 dapat dilihat hasil penanganan penderita karsinoma sel ginjal. Dari 16 penderita karsinoma sel ginjal, 9 penderita $(56,25 \%)$ melakukan tindakan nefrektomi dan 7 penderita $(43,75 \%)$ tidak melakukan tindakan nefrektomi.

Tabel 9. Distribusi Penderita Karsinoma Sel Ginjal berdasarkan Penanganan

\begin{tabular}{ccc}
\hline \hline Penanganan & Jumlah & $\%$ \\
\hline Nefrektomi & 9 & 56,25 \\
Tidak & 7 & 43,75 \\
Nefrektomi & & \\
\hline Total & 16 & $100 \%$ \\
\hline \hline
\end{tabular}

\section{BAHASAN}

Dari hasil penelitian secara deskriptif retrospektif di bagian Rekam Medik RSUP Prof. Dr. R. D. Kandou Manado dan bagian Patologi Anatomi dalam kurun waktu 5 tahun, yaitu periode 2013-2015 sebanyak 16 kasus, dengan kriteria inklusi bahwa 16 kasus yang didapat di bagian Rekam Medik
RSUP Prof. Dr. R. D. Kandou Manado dan di bagian Patologi Anatomi adalah kasus yang catatan mediknya disimpan atau ditemukan.

Tabel 1 menunjukan bahwa distribusi penderita karsinoma sel ginjal periode 2013-2015, terbanyak pada tahun 2015 yaitu sebanyak 10 kasus (62,5\%), lalu disusul tahun 2014 sebanyak 4 kasus (25\%), dan terakhir pada tahun 2013 sebanyak 2 kasus $(12,5 \%)$ Hasil ini berdasarkan data yang ditemukan di bagian Rekam Medik RSUP Prof. Dr. R. D. Kandou Manado yang menunjukkan tahun 2015 merupakan tahun terbanyak angka kejadian karsinoma sel ginjal.

Pada Tabel 2 didapatkan bahwa kelompok umur tersering yang menderita karsinoma sel ginjal adalah kelompok umur 51-65 tahun sebanyak 8 kasus (50\%). Pada penelitian sebelumnya dimana pasien dengan diagnosa karsinoma sel ginjal adalah yang sudah lanjut usia lebih banyak dari usia muda. Umur 40-70 tahun merupakan umur yang paling umum dari penyakit ini. Penelitian lain juga mengungkapkan rata-rata usia ketika mereka di diagnosis adalah 64 tahun atau pada dekade ke-6 dan ke-7. Karsinoma sel ginjal sangat jarang pada orang muda dari usia 45 tahun. ${ }^{4}$

Pada Tabel 3 tentang distribusi karsinoma sel ginjal menurut jenis kelamin, didapatkan bahwa penyakit karsinoma sel ginjal lebih banyak terjadi pada laki-laki yaitu sebanyak 11 kasus (68,75\%), sedangkan pada perempuan sebanyak 5 kasus (31,25\%). Pada penelitian sebelumnya dimana penyakit karsinoma sel ginjal ini dua kali lebih sering pada lakilaki daripada perempuan. Hal ini juga karena pada penyakit RCC mewakili kanker paling umum ke-7 pada pria dan kanker paling umum ke-9 pada wanita. ${ }^{8}$

Pada Tabel 4 dan 5 didapatkan letak karsinoma sel ginjal periode 2013-2015 yaitu sebanyak 16 kasus (100\%) mengalami karsinoma sel ginjal letak unilateral, dimana yang terbanyak terdapat pada posisi dextra yaitu sebanyak 9 kasus $(56,25 \%)$. Seperti penelitian yang sudah 
dilakukan sebelumnya, letak unilateral memang lebih sering dibandingkan dengan bilateral, dimana kejadian tumor pada kedua sisi atau bilateral hanya terdapat pada $2 \%$ kasus saja. ${ }^{9}$

Pada Tabel 6 didapatkan hasil histopatologi pada penderita karsinoma sel ginjal yaitu tidak diketahui atau tidak ada data di bagian Rekam Medik dan bagian Patologi Anatomi sebanyak 9 kasus $(56,25 \%)$ dan 7 kasus $(43,75 \%)$ mendapatkan hasil histopatologi berupa clear cell. Ada beberapa subtipe dari RCC, namun yang paling sering adalah tipe clear cell yaitu sekitar 70-80\%. Pada penelitian sebelumnya mengungkapkan pada hasil histologi tipe clear cell konvensional merupakan prognosis yang paling buruk. ${ }^{9}$

Pada Tabel 7 didapatkan bahwa dari 16 kasus karsinoma sel ginjal, didapatkan keluhan tebanyak yaitu nyeri pinggang sebanyak 14 kasus $(87,5 \%)$. Di dalam penelitian sebelumnya, hematuria merupakan keluhan yang paling banyak dari trias klasik. Hal ini tidak sesuai dengan penelitian yang dilakukan. Sejumlah besar pasien dengan RCC hadir dengan trias klasik atau gejala umum ini tidak selalu ditemukan. ${ }^{1}$ Sebagian besar pasien hanya menunjukkan satu atau dua gejala dari trias klasik tersebut. Pada penelitian sebelumnya, frekuensi manifestasi klinis tertinggi yaitu ditemukannya trias klasik $(42,5 \%)$, lalu diikuti demam (22,5\%), nausea/muntah $(17,5 \%)$, dan penurunan berat badan $(5 \%){ }^{8}$

Tabel 8 menunjukkan bahwa hasil dari hasil metastasis, terdapat 10 kasus $(62,5 \%)$ tidak mengalami metastasis ke berbagai organ. Di dalam penelitian sebelumnya, metastasis paru merupakan metastasis yang tersering yaitu sekitar $45 \%$ dari semua metastasis RCC, sehingga mewakili letak anatomi yang paling umum dari RCC yang disebarluaskan. ${ }^{7}$

Tabel 9 menunjukkan bahwa penanganan pada penderita karsinoma sel ginjal yaitu sebanyak \%9 kasus $(56,25)$. Nefrektomi merupakan manajemen RCC yang paling utama. Pasien RCC yang di rawat di RSUP Prof. Dr. R. D. Kandou
Manado ini telah dilakukan nefrektomi radikal. Nefrektomi radikal merupakan mengangkat ginjal beserta fasia gerota dan yang terikat dengan kelenjar adrenal dan juga jaringan lemak di daerah sekitar ginjal. ${ }^{1} \quad$ Pasien-pasien juga telah mendapatkan penanganan kemoterapi dengan regimen avastin dan juga telah diberikan obat-obatan. Pada beberapa penelitian mengatakan bahwa pasien yang diberikan kemoterapi biasanya sangat resisten, sehingga kemoterapi bukanlah penanganan standar pada penyakit RCC. ${ }^{4}$

\section{SIMPULAN}

Dari hasil penelitian dan bahasan dapat disimpulkan bahwa angka kejadian karsinoma sel ginjal di RSUP Prof. Dr. R. D. Kandou Manado selama periode 20132015 yaitu sebanyak 16 kasus dengan kasus terbanyak pada tahun 2015 dan kasus paling sedikit yaitu pada tahun 2013 sebanyak 2 kasus. Mayoritas kasus terdapat pada kelompok umur 51-65 tahun, jenis kelamin laki-laki, dengan keluhan nyeri pinggang dan tanpa metastasis dan

Lokasi karsinoma terbanyak unilateral dengan posisi dekstra. Hasil histopatologik terbanyak yaitu 9 kasus tidak diketahui karena data tidak lengkap dan 7 kasus dengan hasil clear cell. Tidak semua penderita karsinoma sel ginjal dilakukan penanganan nefrektomi.

\section{SARAN}

1. Data-data pasien pada bagian rekam medik sebaiknya disimpan dan ditata secara baik agar lebih memudahkan dalam melakukan pencarian jika sewaktu-waktu dibutuhkan.

2. Sebaiknya masyarakat lebih memperhatikan kesehatan dan memperbaiki gaya hidup agar dapat mencegah terjadinya karsinoma sel ginjal.

3. Jika terdapat nyeri pinggang yang hebat dan teraba massa pada pinggang serta adanya perdarahan di urin sebaiknya segera memeriksakan diri ke dokter. 
DAFTAR PUSTAKA

1. Umbas R, Manuputty D, Sukasah CL, Swantari NM, Achmad IA (alm), Bowolaksono, et al. Saluran kemih dan alat kelamin lelaki. In: Sjamsuhidajat R, Karnadihardja W, Prasetyono TOH, Rudiman R, editosr. Buku Ajar Ilmu Bedah (3rd ed). Jakarta: EGC, 2010; p.850-95.

2. Ferlay J, Soerjomataram I, Dikshit R, et al. Cancer incidence and mortality worldwide: sources, methods and major patterns in GLOBACON 2012. Int $\mathrm{J}$ Cancer 2015;136:359-86.

3. Seno DWH, Mochtar CA, Umbas R. Terapi sistemik terkini pada karsinoma sel ginjal metastatik. Indonesian Journal of Cancer. 2011; 5:105-12.

4. Protzel C, Maruschke M, Hakenberg OW. Epidemiology, aetiology, and pathogenesis of renal cell carcinoma. European Association of Urology. 2012: Suppl 12:52-9.

5. Konety BR, Dreicer R, Williams RD. Renal parenchymal neoplasms. In: Tanagho Emil A, McAninch Jack W, editros. Smith's General Urology (16th ed). San
Francisco: Mc Graw Hill, 2003; p. 34662.

6. Sankineni S, Brown A, Phill M, Cieciera M, Choyke PL, Turkbey B. Imaging of renal cell carcinoma. Urologic Oncol. 2016;34:147-52.

7. Brufau BP, Cerqueda CS, Villalba LB, Izquierdo RS, Gonzalez BM, Molina CN. Metastatic renal cell carcinoma: Radiologic findings and assessment of response to targeted antiangiogenic therapy by using multidetector CT. RadioGraphics. 2013;33:1691-8.

8. Nguyen DP, Vertosick EA, Corradi RB, Vilaseca A, Benfante NE, Touijer KA, et al. Histological subtype of renal cell carcinoma significantly affects survival in the era of partial nephrectomy. Urologic Oncol. 2016; 34:1-7.

9. Escudier B, Eisen T, Porta C, Patard JJ, Khoo V, Algaba F, et al. Renal cell carcinoma ESMO Clinical Practice Guidelines for diagnosis, treatment and follow up. Oxford Journals. 2012;23:65-66. 